\title{
The Economic Impact of COVID-19 in Pacific Island Countries and Territories
}

\author{
Phil Bright and David Abbott
}

This chapter describes the impact of COVID-19 on the socio-economic situation of the Pacific Island Countries and Territories (PICTs) during the first nine-months of 2020. Fortunately, only six of the PICTs have had cases of COVID-19 to date, but the far-reaching social and economic effects on such a vulnerable region are significant. This chapter highlights the economic impacts currently being felt, and those which are being forecast for the near future. The chapter is primarily focused on the tourism sector, which is one of the principal industries for the region providing livelihoods for people in both the formal and informal sectors. Spatial analysis of the Pacific situation is limited, but a few examples are presented.

\subsection{Introduction}

When people think of the Pacific Islands, they often imagine the postcard photo of coconut trees, white sand and turquoise water. This is certainly the case for parts of the Pacific, but in reality the region is very varied with low-lying atoll countries interspersed with high, mountainous and sometimes volcanic islands. The region is made up of thousands of islands spread out across a vast ocean ranging in size from the atoll country of Tokelau with a population of a little over 1,500, to the rugged, and mountainous country of Papua New Guinea with a population of almost 9 million.

The region is also very cultural and ethnically diverse. This is manifest in the more than 800 individual languages in Papua New Guinea (PNG) and the regionally recognised Melanesian, Micronesian and Polynesian sub-regions. Each with its own distinct, yet varied cultures and customs.

In total the Pacific region currently comprises a little over 12.3 million inhabitants and is characterized by relative fast population growth in many countries, notably in Melanesia, and rapid urbanisation (as nationally defined) in countries across the region. The population is expected to increase by more than fifty percent and to pass 20 million in the next 30 years ${ }^{1}$.

The region is also among the most vulnerable to natural disasters and climate change. Excluding PNG, $90 \%$ of Pacific Islanders live within $5 \mathrm{~km}$ of the coast [1] making them highly susceptible to sea level rise and extreme weather events, including storm surges, cyclonic damage and coastal flooding. There have also been incidents of earthquake-related tsunamis causing serious loss of life and infrastructure damage in Samoa, Solomon Islands and PNG; and volcanoes have caused similar damage in Vanuatu. Having geospatial data that accurately maps these areas of vulnerability will be essential as the consequences of climate change affect the fragile island environments.

\footnotetext{
${ }^{1}$ Pacific Data Hub.stat. Population Projections. https://stats.pacificdata.org/
} 


\subsection{Socio-economic Context}

Although PICTs being small islands in a vast ocean, are often regarded as isolated from the rest of the world and the vagaries of the global economy, in reality they are as fully integrated as any other nation. The economies of the Pacific are very open with merchandise trade, the aggregate value of both imports and exports often exceeding the value of their national Gross Domestic Product (GDP). And most of the smaller, resource-poor, small island states experience persistent balance of trade deficits that amount in some cases to over 70 percent of GDP. In recent years increases in fishing licence fees, revenues from sovereign wealth and trust funds have helped to cover these deficits.

PICTs are also highly dependent on foreign development assistance (increasingly so in the current pandemic environment), worker and family remittances, and receipts from tourism, all of which are directly and closely linked to the state of the global economy. This means they are highly susceptible to the impact of external events or shocks, including the consequential effects of the pandemic even when the health aspects have been largely avoided.

The region is therefore very dependent on the "outside" with remittances being equivalent to around $40 \%$ of Tonga's GDP ${ }^{2}$, and tourism is estimated to account for between 20-30\% of economic activity in many countries including Samoa, Tonga and Vanuatu [2]. There is also a significant dependency on Overseas Development Assistance (ODA) with half of the PICTs falling in the top 15 countries in the world in terms of net ODA received per capita (US\$) ${ }^{3}$.

Lack of economic opportunities in the small island economies of the Pacific have led to high rates of youth unemployment and significant rural-to-urban-to-overseas migration. This has led to rural depopulation in a number of countries, increasing rural dependency ratios and a reduction in the contribution of rural agriculture to national GDPs. Gender inequality, increasing levels of hardship and basic-needs poverty and the incidence of domestic violence also present significant challenges in the region. Poor health outcomes, largely the result of the prevalence of non-communicable diseases (NCDs) which represent a very high, $75 \%$, of mortality, putting the region above the global average, are also a major challenge [3]. The high prevalence of NCDs also makes Pacific people potentially highly susceptible to the COVID-19 virus and its complications; a major reason for the strict border controls and international movement instituted by most of the island governments.

\subsection{Coming of COVID-19 and How It Is Reported in the Pacific Region}

\subsubsection{The Spread of Covid-19 in the Region}

The first case of COVID-19 appeared in French Polynesia on 10 March 2020. Over the next 3 weeks, Guam, New Caledonia, Fiji, PNG and the Commonwealth of the Northern Marianas detected their first cases.

As has been the case globally, PICTs adopted strict measures to close their borders and restrict domestic movement. The timeliness of these measures have resulted in many PICTs recording no cases of COVID-19, and others being able to effectively limit, at least initially, the numbers of cases entering the country. New Caledonia for example, significantly reduced international travel starting on the 18th of March when the first case of COVID was diagnosed. The authorities then enforced a nation-wide four weeks of confinement from the 24th of March, closing schools and non-essential services, and prohibiting leisure activities apart from limited exercise within $1 \mathrm{~km}$ of place of

\footnotetext{
${ }^{2}$ World Bank Data. Personal Remittances, received (\% of GDP) https://data.worldbank.org/indicator/BX. TRF . PWKR.DT.GD.ZS?most_recent_value_desc=true

${ }^{3}$ World Bank Data. Net ODA received per capita (current US\$) https://data. worldbank.org/indicator/DT. ODA. ODAT.PC.ZS?most_recent_value_desc=true
} 
residence. Shopping was allowed, though any movement outside the place of residence required an "attestation de déplacement dérogatoire" which meant everyone moving outside of their immediate residential area needed to carry a statement indicating why the person had left the house. Such an attestation needed to be carried by every household member ${ }^{4}$.

As of 15 September there were 3,656 COVID-19 cases (Figure 26.1) and 38 reported deaths in the Pacific, with significant increases reported in the previous four weeks, notably in Guam, French Polynesia and PNG (Figure 26.2) ${ }^{5}$. In New Caledonia where border restrictions were still some of the tightest globally, there were only 26 cases, with none of them being from community transmission.

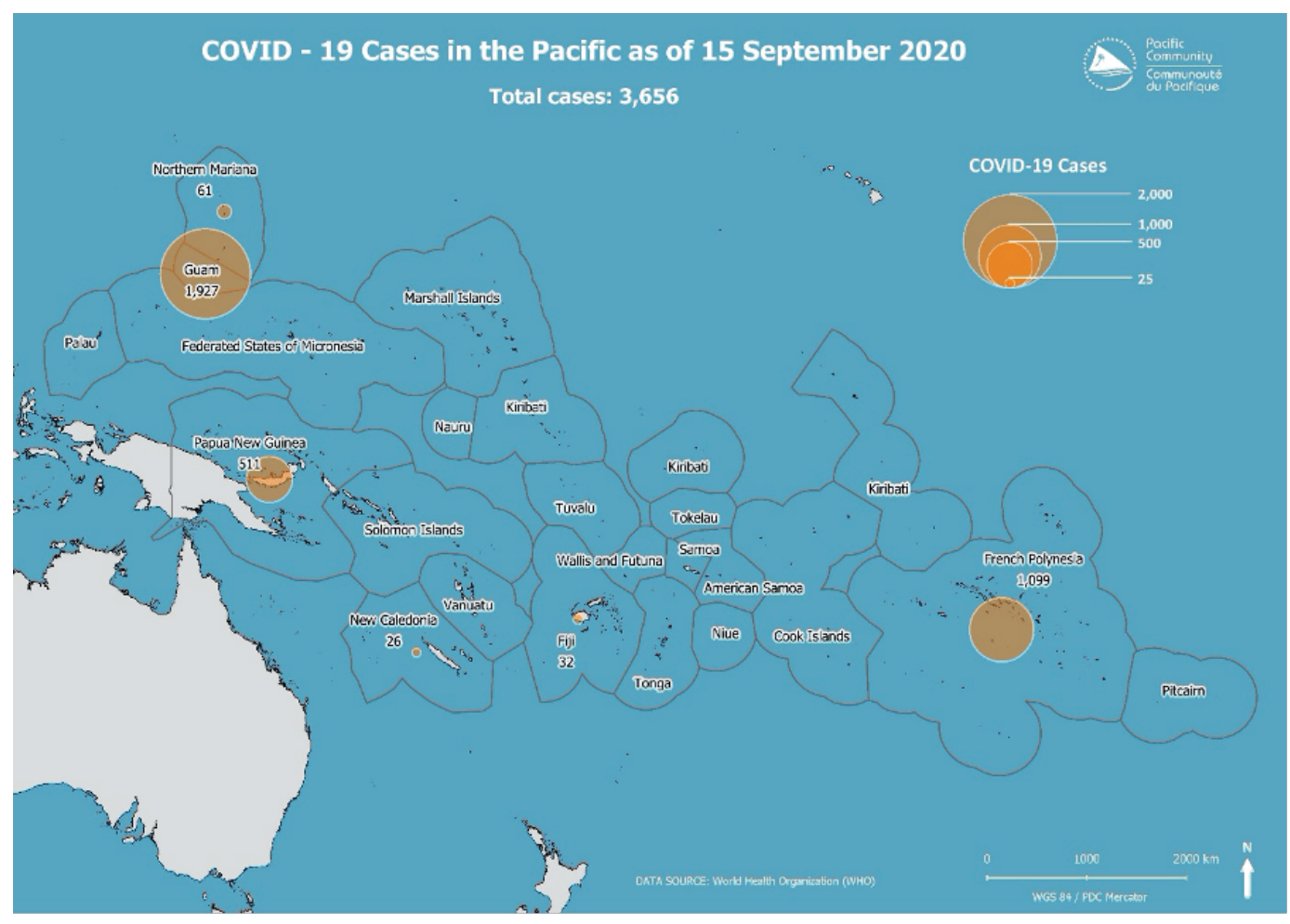

FIGURE 26.1

COVID-19 Cases in the Pacific as of 15 September 2020 (Source: See footnote 5)

\subsection{Mapping COVID-19 in the Pacific}

Robust spatial data infrastructures in the Pacific's twenty-two countries and territories would be ideal to prepare for and manage a pandemic like COVID-19; "A virus-resilient economy requires knowing exactly where infected people are, living conditions, and access to medical services - all of which hinges on geospatial information" [4].

Although there has been increased adoption of GPS-locational data, satellite and drone imagery, and improvements in the mapping of services and infrastructure, what is generally lacking across

\footnotetext{
${ }^{4}$ Gouvernement de la Nouvelle Calédonie. Info coronavirus Covid-19. https://gouv.nc/coronavirus

${ }^{5}$ Pacific Community. COVID-19: Pacific Community Updates. https://www.spc.int/updates/blog/2020/09/ covid-19-pacific-community-updates
} 


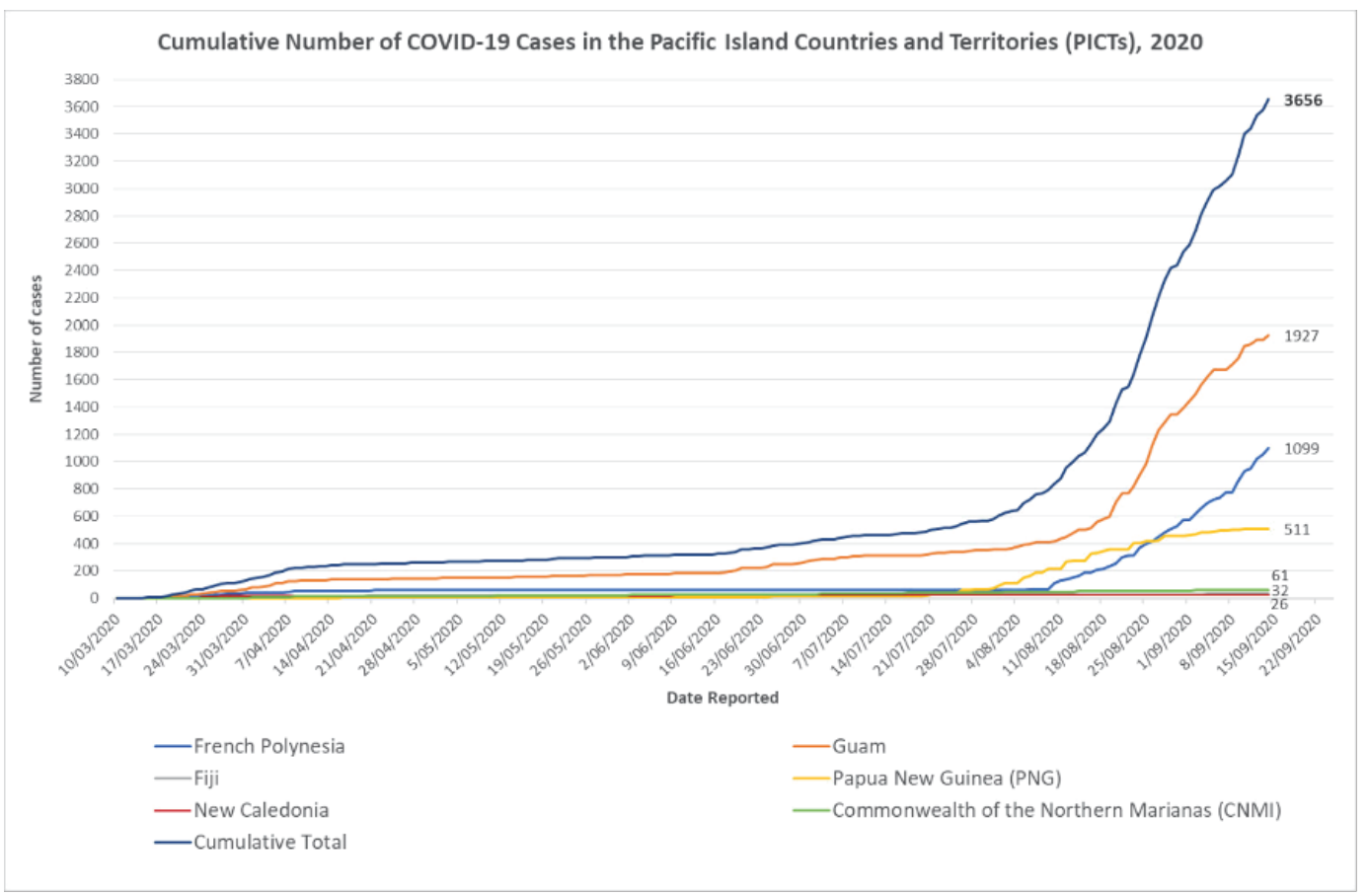

\section{FIGURE 26.2}

Cumulative COVID-19 Cases in the Pacific as of 15 September 2020 (Source: See footnote 5)

the region is a way to easily access, utilise and link these disparate data sources. Mobile phone data is also being more frequently utilised and some crowdsourcing of data in disaster situations.

Population grids such as the one shown in Figure 26.3, developed by the Statistics for Development Division (SDD) at the Pacific Community $(\mathrm{SPC})^{6}$, are an example of where value-added spatial analysis has been undertaken and can be used in applications such as disaster preparedness and also disaster relief.

To date the use of geospatial tools to analyse the COVID-19 situation at a sub-national level in the region has not been widespread. This is to a large degree because of the limited availability of detailed COVID incidence data, the required local-level socio-economic data, and the resources to perform the analysis. The most detailed mapping the authors are aware of, is that which has been done by the World Health Organisation (WHO) which shows data at a provincial level for most of the PICTs affected by COVID-19.

There is also the Pacific COVID-19 Response Map created by the Australian National University (ANU) CartoGIS, the Australia Pacific Security College (PSC), and the ANU Department of Pacific Affairs to monitor the ongoing responses of Pacific Island Countries and Territories ${ }^{7}$. The map is updated weekly.

\subsubsection{Communicating the Pandemic}

Communicating nationally important health messages across the countries of the region is frequently very difficult. Internet, $\mathrm{TV}$ and mobile phone penetration is very low in many of the poorer and widely dispersed mountainous countries of Melanesia, and amongst the small atoll and island states with widely scattered, small and often isolated communities. Not only is communication difficult but also the collection of the "real-time" data required to monitor and

\footnotetext{
${ }^{6}$ Pacific Community, Statistics for Development Division. Covid-19. https://sdd.spc.int/disasters-data/ covid-19

${ }^{7}$ Policy Forum. Pacific COVID-19 Map. https://www.policyforum.net/pacific-covid-19-map/
} 


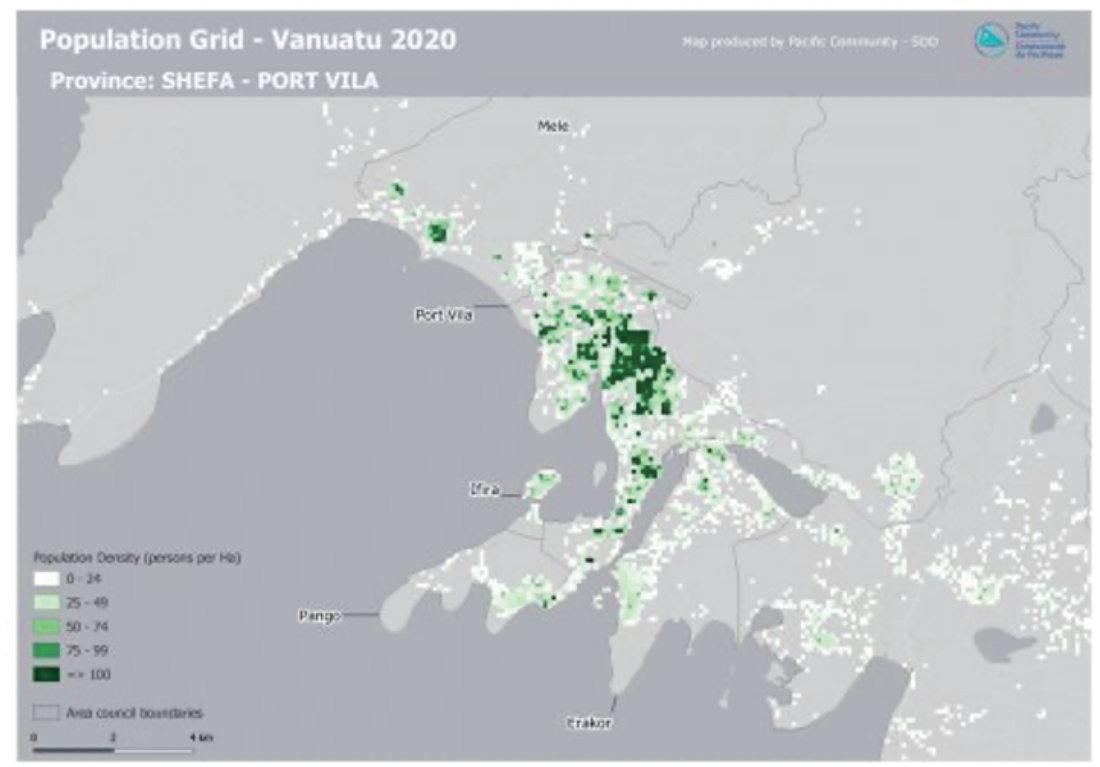

\section{FIGURE 26.3}

Population Grid of Port Vila, Efate, Vanuatu with each cell representing $100 \mathrm{~m}^{2}$ (Source: See footnote 6)

address disaster-related events, such as the COVID-19 pandemic and the tropical cyclones that are a regular occurrence for many.

\subsubsection{Awareness and Coping Strategies}

In an attempt to overcome this information and communication constraint, the World Bank conducted the first round of High Frequency Phone Monitoring (HFPM) Surveys at the end of June 2020, interviewing more than 3,000 respondents in PNG [5] and over 2,600 in Solomon Islands [6]. The surveys showed that fortunately there was a high degree of COVID awareness, with over 95\% of PNG respondents and $91.8 \%$ of respondents in Solomon Islands reporting that they were aware of the pandemic; awareness in the Solomon Islands urban centres at $97.4 \%$ was however a little higher than in the rural areas (90.9\%).

The most important sources of information were reported as the radio $53.2 \%$ and $28.4 \%$ in Solomon Islands and PNG respectively, followed by family \& friends ( $7.1 \%$ \& $14.7 \%)$, community leaders $(9.0 \% \& 13.0 \%)$ and newspapers $(2.1 \% \& 15.2 \%)$. In Solomon Islands the internet and social media $(7.4 \%)$ and health clinics $(6.2 \%)$ were also important. These results were reflected across all levels of respondent suggesting that radio is a cost effective and equitable means of providing information to the public at large [6]. See Figures 26.4 and 26.5 below for the PNG results.

The PNG HFPM survey also looked at the coping strategies of those who had lost their jobs or seen their income reduced as a result of the pandemic. Coping strategies for these families included both selling some of their own local produce or livestock to raise needed cash (over one-third of respondents in PNG and just over seventeen percent in Solomon Islands), and/or reducing food or non-food consumption expenditure, an average of $28 \%$ in PNG and just over $52 \%$ in Solomon Islands. Around one quarter of households in PNG and almost half of households in Solomon Islands reported receiving cash or borrowing from family or friends and in PNG a quarter also reported receiving other forms of assistance from this source. In Solomon Islands almost $45 \%$ found ways to earn extra money, $27 \%$ used credit or delayed payments and $18.8 \%$ received assistance from their church, in PNG only $10.9 \%$ reported receiving assistance from this last source.

Of particular concern however was the report from PNG that just over $50 \%$ of households had 


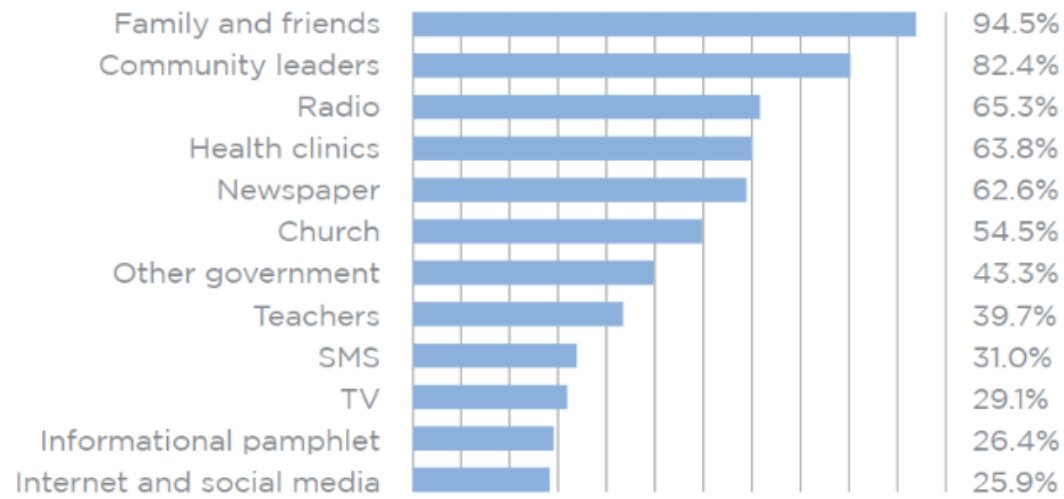

\section{FIGURE 26.4}

Sources of Information on COVID-19. World Bank High Frequency Phone Survey, PNG Round 1 June 2020 [6]

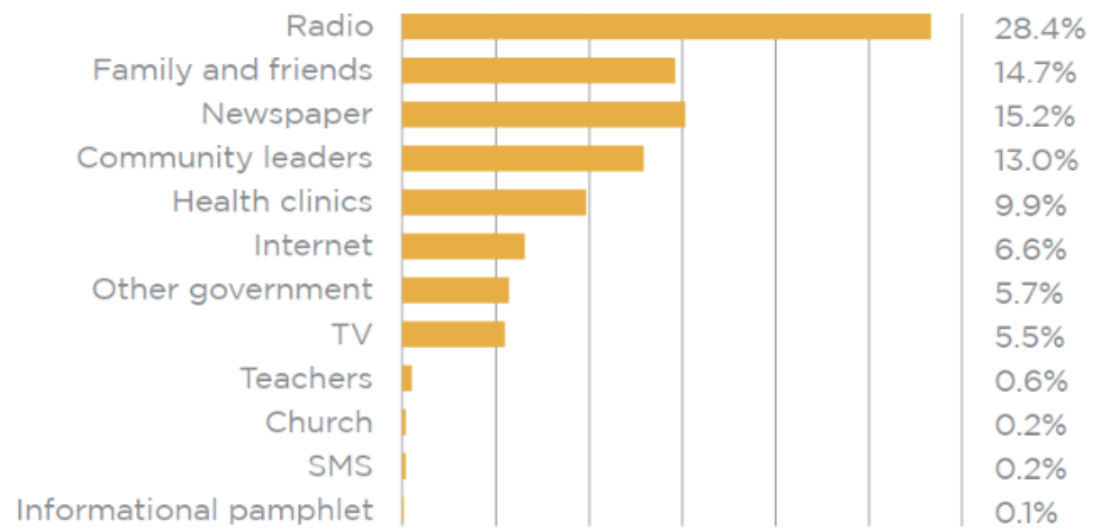

\section{FIGURE 26.5}

Main Source of Information on COVID-19. World Bank High Frequency Phone Survey, PNG Round 1 June $2020[6]$

removed children from school. The HFPM did not provide sufficient information to definitively identify the underlying reason for this and it could have been a combination of many factors including financial cost, concern at school-level COVID-19 transmission and the need for additional help in domestic food cultivation. Subsequent rounds of the surveys are expected to delve more deeply into the effects on inequality, gender and children.

\subsection{What Is Being done to Monitor the Impact of COVID-19 via Economic Statistics?}

The pandemic is adversely affecting almost all activities in the economic and social spheres of the Pacific region. Economic activity in the Pacific Islands has slowed at an unprecedented rate and 
scale, triggering major crises in the tourism, trade, financial, construction, personal services and government sectors.

It is also having a serious impact on the informal parts of Pacific economies. For example, many women are involved in selling food and other items in local markets or handicrafts in hotels and tourism sites. With many of these now closed or devoid of tourists the livelihoods of a large number of these informal vendors will have been destroyed. Job losses, restrictions on small businesses and declining remittance flows are therefore likely to be having a major impact on the levels of hardship and poverty being experienced by households and families across the region.

More than three-quarters of the respondents in both HFPM Surveys said they were worried about their household finances in the next month. In PNG there was a bias towards those in the bottom $40 \%$ (poorer population) where more than $85 \%$ of households were worried (Figure 26.6).

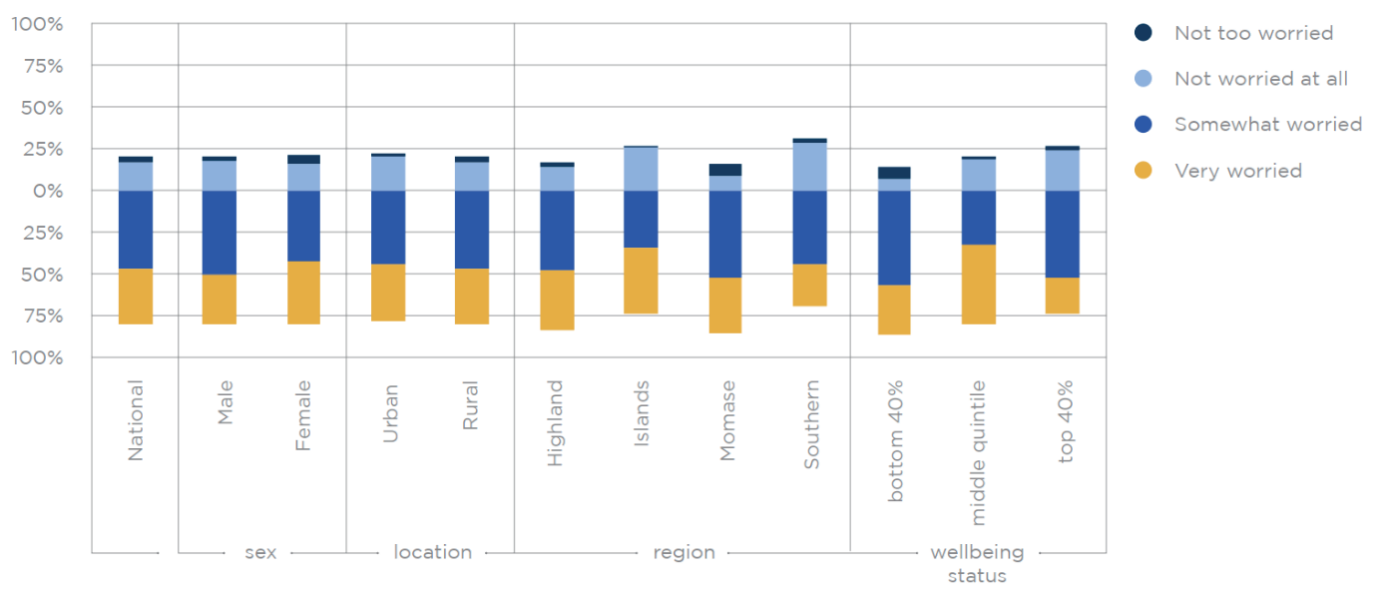

FIGURE 26.6

Financial Anxiety (by sex, location, and well-being status). World Bank High Frequency Phone Survey, PNG Round 1 June 2020 [6]

\subsubsection{Economic Impacts and Fiscal Responses}

All Pacific countries announced immediate fiscal responses to COVID in March or April [7]. Many have expanded on these as the pandemic has continued to disrupt economic activity, for example the US $\$ 37.5$ million the Solomon Islands Government is injecting into key sectors. These measures include tax breaks for tourism operators; subsidies for copra and cocoa exporters; concessional loans for large private companies and equity injections for public/private companies. There is also a ramping up of donor-funded infrastructure projects with a focus on local employment [8].

Notwithstanding these early fiscal responses, the extent of the initial and underlying economic impacts are now being seen in available quarterly GDP data and budget forecasts from countries across the region. For example, in the first half of 2020 GDP in Samoa was an estimated 7.7\% (in constant 2013 prices) below the level of the first half of 2019. The tourism-related sectors in the Samoa economy were the worst affected with the value-added contribution to GDP of the accommodation and restaurant industries falling by $53.3 \%$ and manufacturing, including of food and beverages, falling by a quarter over the same period ${ }^{8}$.

The state of the tourism sector in Fiji and elsewhere tells a similar story. In the second quarter of 2020 there were effectively zero tourist arrivals to Fiji, Samoa and Solomon Islands. Employment in the accommodation industry in Samoa was down by $26.6 \%$ in the second quarter of 2020 compared to the same period of 2019 ; decreases in employment in construction (-6.0\%), restaurants $(-3.0 \%)$ and personal services $(-4.3 \%)$ were also recorded.

\footnotetext{
${ }^{8}$ Samoa Bureau of Statistics; Gross Domestic product June 2020, September 2020
} 
With tourism being so important to the Pacific, the impact will be felt in areas including government finances, supply chains and transport. The tourism industry in Fiji accounts for roughly $35 \%$ of GDP which is why the impact of COVID-19 is estimated to be creating such a large contraction in the Fijian economy.

The impact on the Fiji economy was clearly outlined by the Fiji Finance Minister in his 2020-21 budget address. The Minister reported that by July 115,000 workers, approximately one-third of Fiji's total workforce, had either had their hours reduced or had lost their jobs entirely as a result of the collapse in tourism [9]. As a consequence, the 2020-21 budget projected a $21.7 \%$ contraction in GDP in 2020 leading to a forecast budget deficit of $20.2 \%$ of GDP in the 2020-21 fiscal year ${ }^{9}$.

Somewhat unusually it is those in formal employment that are experiencing the worst of the economic impacts. Most natural disasters deprive rural populations of their livelihoods through destroyed crops and damaged rural infrastructure. This time the pandemic is causing job and income losses principally amongst those previously in formal employment, especially in the tourism and services sector. The border closures and lockdowns have left rural populations relatively unscathed and with continued access to their crops, livestock and fishing grounds. There is, however, anecdotal evidence to suggest that many urban families are returning to their traditional villages and that such return migration, is having adverse impacts through the over-exploitation of coastal fisheries and traditional plantations.

A reduction in sources of income and disturbed supply chains are also impacting Pacific food systems. Governments across the region are implementing various initiatives to enhance the production of healthy local produce. These include distribution of fruit and vegetable seedlings to farmers and families; fast-tracking of existing agriculture initiatives; and distribution of Tilapia fingerlings and feed to stock backyard ponds. Government authorities in some countries have also been buying produce from farmers and delivering to vendors during lockdown periods, where trade in local produce declined due to domestic travel restrictions [10].

The coming fiscal year is likely to be very tough for all Pacific countries. Reduced public revenues coupled with increasing demands for higher public expenditure to support struggling businesses, to provide social protection for the most vulnerable and those being made unemployed by the closed borders, are undermining fiscal stability for many Pacific countries. Demands for external budget support from bilateral donors, international finance institutions and borrowing are increasing [11].

\subsubsection{Social Protection}

Prior to the arrival of the pandemic and its serious consequences for employment and incomes, it was estimated that across the region as a whole, around one-in-four families were living at or below their respective national basic-needs poverty lines [12]. This suggests that over 3 million Pacific Islanders were struggling to meet a minimum standard of living in their own countries. Estimates by the Australian National University (ANU) Development Policy Centre [13] and the Statistics for Development Division of the Pacific Community (SPC). indicate that if household consumption expenditure declines by an average of between $30 \%-50 \%$ an additional one million people will likely fall below the basic-needs poverty lines during the pandemic ${ }^{10}$.

Throughout the Pacific region national governments play a significant role in almost all Pacific economies. However social protection has not generally been a high priority in public expenditure. Traditional Pacific systems of caring and sharing amongst families, kinship groups, communities and church congregations have been left to carry much of the burden. However, these traditional systems have come under pressure as Pacific economies have monetized, migration has increased and the structural nature of societies has changed. Only in a few Pacific countries have social protection systems kept pace with the changing social environment.

Although spending on social protection has increased in recent years (from the equivalent of $4.1 \%$ of GDP in 2009 to $6.0 \%$ in 2015) [14, p 74] the distribution of benefits tends to favour those in the formal sectors of the economy, primarily through the social insurance provided by national

\footnotetext{
${ }^{9}$ Pacific Community, Statistics for Development Division. Covid-19. https://sdd.spc.int/disasters-data/ covid-19

${ }^{10}$ Pacific Community, Statistics for Development Division. Covid-19. https://sdd.spc.int/disasters-data/ covid-19
} 
provident funds and social security administrations. Frequently those engaged in the informal or semi-subsistence sectors have been excluded.

Social assistance is usually universally available to those who meet the criteria for each particular benefit but is nevertheless estimated to only reach around $20 \%$ of intended beneficiaries across the region. Social assistance benefits generally provide limited payments for vulnerable people, including the elderly, people living with a disability and for child welfare. Although benefits are comparable, on average, to those seen in Asia, social protection spending in the Pacific reportedly favours the nonpoor over the poor, and men over women [14, p 63]. In 2015 the ADB estimated that, in total, social protection covered only $31.2 \%$ of intended beneficiaries in the region [14, p 21]. The extent of the social and economic damage caused by the pandemic has caught most countries off-guard, and social protection responses to COVID are therefore building on a limited base.

With fiscal constraints and limited institutional structures to establish and manage large scale social protection schemes, to date only a few countries have introduced new or increased levels of social protection benefits; these include Cook Islands, Fiji, Samoa and Tuvalu. Only Fiji has a broad poverty-targeted social welfare programme, and thus has institutional arrangements in place to introduce new social protection measures.

But like most other Pacific countries the social protection system in Fiji does not provide comprehensive support for those experiencing such sudden and widespread loss of employment and income. In its 2020-21 budget Fiji allocated around US $\$ 50$ million (approximately 1\% of GDP) in funding for unemployment assistance in 2020-21. If the pandemic-induced economic recession lasts well into 2021 that allocation will not go very far to alleviate the increasing hardship being experienced. The newly unemployed in Fiji and elsewhere across the region will need to find coping strategies to meet their final commitments and basic needs. The newly unemployed in Fiji and elsewhere are largely on their own.

Many governments including Fiji, have allowed those being made unemployed to access a proportion of their own savings in national provident funds. This is generally a nil-cost measure for governments, and one that favours the minority who have provident fund savings. It certainly assists in alleviating the most urgent needs but comes at the expense of depleting savings for retirement. Moreover, it does little for those in the informal sectors. Indeed, some countries, including Fiji, have a condition that access to central government assistance is only available to those who have completely exhausted their own provident fund and other savings, and even then, will receive only FJD220 per fortnight.

\subsection{What We Can Learn from COVID-19 for Future Pandemics or Other Disasters?}

The social and economic impact of COVID-19 in the Pacific, as with the rest of the world, will likely long outlast the discovery and application of the first vaccines and the reopening of economies. Many small businesses have already closed with their cash flows having already dried up and with no access to additional capital or lines of credit. The confidence of these small entrepreneurs and family businesses, and that of other investors will likely take years to fully recover, indeed if ever [15].

The Pacific is a vulnerable region, whether it be from impacts related to cyclones, earthquakes or other natural disasters, or from pandemics such as COVID-19. Indeed, it might be argued by many in the health sectors of the PICTs that there is an ever-present epidemic situation involving NCDs. These might not have the same macroeconomic consequences as the current COVID pandemic, but at the household and family levels the impact can be just as devastating as the complications often associated with NCDs that remove individuals from the labour force, either as sufferers or as carers.

Travel restrictions and lockdowns have created a perfect storm of social and economic disruption to the small, fragile economies which are highly dependent on external drivers and resources. With 
small domestic economies and few economies of scale it is hard to offset the magnitude of the economic losses caused by the closing of borders and disruptions to trade.

"Fiscal space" to enable more resources to be channelled towards public health, providing economic stimulus and improving social "safety nets" [16] can be created through avoiding wasteful spending and improving cost-effectiveness in situations where raising additional revenues might be difficult. Likewise, encouraging household production of fresh produce for home consumption or sale in local markets can reduce dependency on purchased goods, particularly imports of food.

Although the pandemic has raised the profile of social protection as a major policy concern, much remains to be done. For example, would it be desirable or affordable to introduce a national minimum income or social protection floor and better targeting of those in need, especially people with disabilities, the poorest and most vulnerable. The social impact of COVID-19 further highlights the need for improved public sector performance in the delivery of essential public sector service provision including health, education and welfare. The inter-related issues of affordability, social preferences and performance might be better served by engaging more cooperatively and effectively with civil society and the private sector.

\subsection{Building Preparedness Through Better Data}

Administrative systems and data collection processes lack the efficiencies which generally exist in more developed countries. This can result in data being hard to access and collate, and in some countries with limited statistical capacity the data might not be collected at all. This makes it difficult to effectively prepare for a pandemic or such a similar event, or to monitor the impacts should such an event occur. In addition, sub-national disaggregation is either non-existent or data is only disseminated in a highly aggregated form, making detailed spatial analysis difficult. This is an area which needs to be improved, not only to assist with the management of pandemics, but to assist in infrastructure planning and building climate change resilience.

The collection of locational data has improved with the utilisation of Global Positioning Systems (GPS) and Computer Aided Personal Interviews (CAPI) during census and survey fieldwork which has facilitated the development of population grids for many PICTs. If pandemic case data were also recorded and disseminated at a highly disaggregated level then more complex analysis would be possible.

More could be done to prepare for future events including natural disasters and pandemics through better data compilation and monitoring of emerging trends and issues. In particular, sharing of administrative data between government ministries, agencies and state-owned enterprises and the national statistics offices could enable data to become available more quickly and more comprehensively.

As connectivity across the Pacific region also improves, the use of "big data" and the wider use of geo-spatial and satellite data from global platforms will allow much greater understanding of how and where Pacific people are living, and how their local environments and livelihoods are being affected by climate change, migration and other shocks and disasters.

The long-term sustainability of the Pacific islands, especially the low-lying atolls and islands depends on the regular monitoring and assessment of these factors and events on the people and their social-economic environments.

\section{References}

[1] Neil L. Andrew, Phil Bright, Luis de la Rua, Shwu Jiau Teoh, and Mathew Vickers. Coastal proximity of populations in 22 Pacific Island Countries and Territories. PLOS ONE, 14(9):1-15, 09 2019. doi: 10.1371/ journal.pone.0223249. 
[2] International Monetary Fund. Pacific Islands Threatened by COVID-19. URL https://www.imf.org/en/News/ Articles/2020/05/27/na-05272020-pacific-islands-threatened.

[3] Pacific Community. COVID-19 is compounding the Pacific's non- communicable disease crisis. URL https://www.spc.int/updates/blog/2020/06/covid-19-is-compounding-the-pacifics-non-communicabledisease-crisis.

[4] World Bank. The role of geospatial information in confronting COVID-19 - Learning from Korea. URL https://blogs.worldbank.org/eastasiapacific/role-geospatial-information-confrontingcovid-19-learning-korea.

[5] Kristen Himelein, James Carroll Waldersee, and Bagus Arya Wirapati. Papua New Guinea High Frequency Phone Survey on COVID-19 - Results from Round 1. World Bank, September 2020.

[6] Kristen Himelein, James Carroll Waldersee, Bagus Arya Wirapati, and Stephanie Eckman. Solomon Islands High Frequency Phone Survey on COVID-19 - Results from Round 1. World Bank, November 2020.

[7] Devpolicy. Constraints on the Pacific response to COVID-19. URL https://devpolicy.org/constraints-onthe-pacific-response-to-covid-19/.

[8] RNZ. Details of Solomon Islands Economic Package Revealed by PM. URL https://www.rnz.co.nz/ international/pacific-news/415823/details-of-solomon-islands-economic-package-revealed-by-pm.

[9] Hon. Aiyaz Sayed-Khaiyum. 2020-2021 National Budget Address. Fiji Parliament. 17 July 2020.

[10] Food and Agriculture Organisation of the United Nations. Impacts of COVID-19 on the Food Systems in the Pacific Small Island Developing States (PSIDS) and A Look into the PSIDS Responses. URL http: //www.fao.org/uploads/pics/COVID-19_impacts_on_food_systems_in_PICs_CRFS_.pdf.

[11] Stephen Howes and Sherman Surandiran. COVID-19 spending across the Pacific: the self-funded, the aid-financed, and the constrained. Australian National University DevPolicy Blog, 20 August 2020. URL https://devpolicy.org/covid-19-spending-across-the-pacific-20200820/.

[12] United Nations Development Programme. The State of Human Development in the Pacific: A Report on Vulnerability and Exclusion in A Time of Rapid Change. UNDP Pacific Centre, 2014. URL https://www .undp.org/content/dam/rbap/docs/Research\%20\&\%20Publications/poverty/State_Human_ Development_Pacific_report.pdf.

[13] Chris Hoy. Poverty and the pandemic in the Pacific. Australian National University DevPolicy Blog, 15 June 2020. URL https://devpolicy.org/poverty-and-teh-pandemic-in-the-pacific-20200615-2/.

[14] Asian Development Bank. The Social Protection Indicator for the Pacific Assessing Progress. Asian Development Bank, 2019. URL https://www.adb.org/sites/default/files/publication/513481/spi-pacific2019.pdf.

[15] Abbott and Pollard. From Response to recovery. Australian National University DevPolicy Blog, 28 August 2020. URL https://devpolicy.org/how-to-get-from-response-to-recovery-in-the-pacific-20200828/.

[16] United Nations Development Programme. The Social and Economic Impact of COVID-19 in the Asia-Pacific Region. UNDP Regional Bureau for Asia and the Pacific, April 2020. URL https: //www . undp.org/content/dam/undp/library/km-qap/UNDP-RBAP-Position-Note-Social-Economic-Impactof-COVID-19-in-Asia-Pacific-2020.pdf. 
$\Longrightarrow$ Taylor \& Francis Taylor \& Francis Group

http://taylorandfrancis.com 